in serum concentration of $24.25(\mathrm{OH})_{2}$-vitamin $\mathrm{D}$ in childhood. Calcif Tissue Int 34:527

7. DeLuca HF, Paaren HE, Schnoes HK 1979 Vitamin D and calcium metabolism. Top Curr Chem Biochem 83:1

8. Dreyer BE, Goodman DBP 1981 A simple direct spectrophotometric assay for 24,25-dihydroxyvitamin $D_{3}$. Anal Biochem 114:37

9. Evans IMA, Colston KW, Galante L, MacIntyre I 1975 Feedback regulation of 25-hydroxycholecalciferol metabolism by vitamin $\mathrm{D}_{3}$. Clin Sci Mol Med 48:227

10. Frazer TE, White NH, Hough S, Santiago JV, McGee BR, Bryce G, Mallon J, A violi LV 1981 Alterations in circulating vitamin D metabolites in the young insulin-dependent diabetic. J Clin Endocrinol Metab 53:1154

11. Hahn TJ, Halstead LR, Haddad JG Jr 1977 Serum 25-hydroxyvitamin D concentrations in patients receiving chronic corticosteroid therapy. J Lab Clin Med 90:399

12. Jones G, Byrnes B, Palma F, Segev D, Mazur Y 1980 Displacement potency of vitamin $\mathrm{D}_{2}$ analogs in competitive protein-binding assays for 25-hydroxyvitamin $D_{3}, 24,25$-dihydroxyvitamin $D_{3}$, and 1,25-dihydroxyvitamin $D_{3}$. J Clin Endocrinol Metab 50:773

13. Juttmann JR, Visser TJ, Buurman C, DeKam E, Birkenhäger JC 1981 Seasonal fluctuations in serum concentrations of vitamin $D$ metabolites in normal subjects. Br Med J 282:1349

14. Kano K, Yoshida H, Yata J, Suda T 1980 Age and seasonal variations in the serum levels of 25-hydroxyvitamin D and 24,25-dihydroxyvitamin D in normal humans. Endocrinol Jpn 27:215

15. Lund B, Sørensen OH 1979 Measurement of 25 -hydroxyvitamin D in serum and its relation to sunshine, age and vitamin $D$ intake in the Danish population. Scand J Clin Lab Invest 39:23

16. Lund B, Clausen N, Lund B, Andersen E, Sørensen OH 1980 Age-dependen variations in serum 1,25-dihydroxyvitamin D in childhood. Acta Endocrinol $94: 426$

17. Nguyen TM, Guillozo H. Garabedian M, Mallet E, Balsan S 1979 Serum concentration of 24,25-dihydroxyvitamin $D$ in normal children and in children with rickets. Pediatr Res 13:973

18. Norman AW, Roth J, Orci L 1982 The vitamin D endocrine system: steroid metabolism, hormone receptors, and biological response (calcium binding proteins). Endocr Rev 3:331
19. Norman ME 1982 Vitamin D in bone disease. Ped Clin N Am 29:947

20. O'Regan S, Chesney RW. Hamstra A, Eisman JA, O'Gorman AM, DeLuca HF 1979 Reduced serum $1,25(\mathrm{OH})_{2}$ vitamin $\mathrm{D}_{3}$ levels in prednisone-treated adolescents with systemic lupus erythematosus. Acta Pediatr Scand 68:109

21. Pitt MJ. Haussler MR 1977 Vitamin D: biochemistry and clinical applications. Skeletal Radiol 1:191

22. Poskitt ME, Cole TJ, Lawson DEM 1979 Diet, sunlight, and 25-hydroxyvitamin $\mathrm{D}$ in healthy children and adults. Br Med J 1:221

23. Rosen JF, Chesney RW, Hamstra A, DeLuca HF, Mahaffey KR 1980 Reduction in 1,25-dihydroxyvitamin $D$ in children with increased lead absorption. N Engl J Med 302:1128

24. Scriver CR, Reade TM, DeLuca HF, Hamstra AJ 1978 Serum 1,25-dihydroxyvitamin D levels in normal subjects and in patients with hereditary rickets or bone disease. N Engl J Med 299:976

25. Shen FH. Baylink DJ. Nielsen RL. Sherrard DJ, Ivey JL, Haussler MR 1977 Increased serum 1.25-dihydroxyvitamin D in idiopathic hypercalciuria. Lab Clin Med 90:955

26. Shepard RM. Horst RL, Hamstra AJ, DeLuca HF 1979 Determination of vitamin $\mathrm{D}$ and its metabolites in plasma from normal and anephric man. Biochem J 182:55

27. Tanaka Y, DeLuca HF 1981 Measurement of mammalian 25-hydroxyvitamin $D_{3} 24 R$ - and lor-hydroxylase. Proc Natl Acad Sci USA 78:196

28. Teitelbaum SL, Halverson JD, Bates M, Wise L, Haddad JG 1977 Abnormalities of circulating $25-\mathrm{OH}$ vitamin $\mathrm{D}$ after jejunal-ileal bypass for obesity. Evidence of an adaptive response. Ann Intern Med 86:289

29. Tjellesen L. Christiansen C 1982 Seasonal variation of vitamin D metabolites in normal adults. A longitudinal study. In: Norman AW, Schaefer K, Herrath DV, Grigoleit H-G (eds): Vitamin D. Chemical, Biochemical and Clinical Endocrinology of Calcium Metabolism. Proceedings of the Fifth Workshop in Vitamin D. Walter de Gruyter, Berlin, p 49

30. Weisman Y, Reiter E. Root A 1977 Measurement of 24,25-dihydroxyvitamin $\mathrm{D}$ in sera of neonates and children. J Pediatr 91:904

31. Whyte MP, Haddad JG Jr, Walters DD, Stamp TCB 1979 Vitamin D bioavailability: serum 25 -hydroxyvitamin $D$ levels in man after oral, subcutaneous, intramuscular, and intravenous vitamin $\mathrm{D}$ administration. $\mathrm{J}$ Clin Endocrinol Metab 48:906

\title{
Calcium-ATPase Activity in Cystic Fibrosis Erythrocyte Membranes: Decreased Activity in Patients with Pancreatic Insufficiency
}

\author{
DORR G. DEARBORN, ROBERT J. WITYK, LYNELLE R. JOHNSON, LOUIS PONCZ, AND \\ ROBERT C. STERN
}

Cystic Fibrosis Center, Departments of Pediatrics and Biochemistry, Case Western Reserve University, Rainbow Babies and Childrens Hospital, Cleveland, Ohio 44106

\section{Summary}

The activity of Ca-ATPase $\left(\mathrm{Ca}^{2+}, \mathrm{Mg}^{2+}\right.$-ATPase, ATP phosphohydrolase, EC 3.6.1.3) was measured in erythrocyte membrane preparations from 37 cystic fibrosis patients, 27 with pancreatic insufficiency and 10 with pancreatic sufficiency, and from 24 healthy controls. The mean maximal calcium-stimulated specific activities, in the absence and presence of purified cal-

Received August 18, 1983; accepted March 12, 1984

Requests for reprints should be addressed to: Dorr G. Dearborn, Department of Pediatrics, Case Western Reserve University, 2101 Adelbert Road, Cleveland, $\mathrm{OH}$ 44106.

This research was supported by Grants AM-08305 and P30-27651 from the National Institute of Arthritis, Diabetes, and Digestive and Kidney Diseases. R. J. W. was a recipient of a student fellowship of the Cystic Fibrosis Foundation. L. P. was a postdoctoral fellow on Training Grant HL-07415. modulin, of the pancreatic sufficient patients $(34.3 \pm 4.2$ and $75.9 \pm 6.9 \mathrm{nmol} / \mathrm{min} / \mathrm{mg}$ ) was indistinguishable from that of controls $(35.8 \pm 2.6$ and $84.3 \pm 4.7 \mathrm{nmol} / \mathrm{min} / \mathrm{mg})$, while both activities of patients with pancreatic insufficiency were significantly decreased $(28.9 \pm 1.3, p<0.02 ; 65.2 \pm 3.0, p<0.001)$ compared to the control group. Similarly, the mean erythrocyte membrane $(\mathrm{Na}+\mathrm{K}) \mathrm{ATPase}$ activity was decreased only for those patients with a history of steatorrhea and who clinically required pancreatic enzyme therapy and had low immunoreactive trypsin levels $(10.6 \pm 0.8$ versus control, $13.4 \pm 1.1$, and pancreatic sufficient patients, $13.3 \pm 1.4 \mathrm{nmol} / \mathrm{min} / \mathrm{mg} ; p<0.025$ ). No correlation was found between any of the ATPase activities and the clinical scores of the patients, suggesting the lack of significant contribution of general clinical status to the activities of those cation transporters. 


\section{Abbreviations}

\section{CF, cystic fibrosis}

EGTA, ethylene glycol bis( $\beta$-aminoethyl ether)- $N, N, N^{\prime}, N^{\prime}$-tetraacetic acid

Cystic fibrosis, a genetic disease involving abnormal epithelial electrolyte transport and exocrine gland dysfunction, is clinically manifested as chronic obstructive lung disease and maldigestion. In recent years, it has become increasing apparent that intracellular calcium has important roles in the regulation of many diverse cellular processes including stimulation-secretion coupling. Since the molecular disorders of the CF exocrinopathy may be closely related to calcium function, we investigated the regulation of intracellular calcium levels in CF cells.

The levels of cytosolic free $\mathrm{Ca}^{2+}$ and thereby its second messenger effects appear to be regulated by protein binding and by transport out of the cytosol by three membrane systems: the plasma membrane Ca-ATPase, the mitochondria, and the endoplasmic reticulum. Total intracellular calcium has been found to be elevated in leukocytes (3), fibroblasts (42), lymphocytes (42), and parotid acinar cells (34) from CF patients. Shapiro and coworkers $(17,42)$ have observed an increased sequestration of calcium by mitochondria from CF fibroblasts. There has been disagreement for the past decade regarding decreased Ca-ATPase activity in CF cells $(1,7,16,18,24,27-30,35$, 47). Recently, Katz and coworkers $(1,27-30)$ have found the greatest difference in calcium-stimulated ATPase activity between CF and control erythrocyte and fibroblast membranes, both in the presence and absence of the activator protein calmodulin. Foder et al. (18), using a different technique for erythrocyte membrane preparation, have observed less dramatic decreases for CF Ca-ATPase activity.

The plasma membrane Ca-ATPase (ATP phosphohydrolase, EC 3.6.1.3, $\mathrm{Ca}^{2+}, \mathrm{Mg}^{2+}$-ATPase) can be conveniently studied in isolation from mitochondria and endoplasmic reticulum in preparations of open erythrocyte ghosts. In addition to activation of the Ca-ATPase by Ca-calmodulin, recent studies on the purified enzyme in reconstituted systems (see Ref. 5) have indicated several possible sources of regulation, some of which may be of biological importance. Different methods of preparing the membranes for assay can result in different content of these regulators. This probably accounts for different observations on CF membranes from various laboratories. An additional factor is the great variability of the activity of the enzyme from one erythrocyte preparation to another even using the same method of preparation $(21,36,47)$.

In this study, we repeated the experiments of Foder et al. (18) using current methodologies, modified to minimize experimental variabilities. In addition, we segregated the $C F$ population into two subpopulations on the basis of clinical and laboratory assessment of pancreatic function. These subpopulations were compared to healthy controls in regards to basal Ca-ATPase activity, calmodulin-stimulated $\mathrm{Ca}$-ATPase activity, and $(\mathrm{Na}+$ K)-ATPase activity.

\section{MATERIALS AND METHODS}

Subjects. Blood samples were drawn from three populations of subjects, healthy controls, age and sex matched to the CF subjects; CF patients, classified as pancreatic insufficient on the basis of history of steatorrhea, need for pancreatic enzyme supplementation, and low levels of plasma immunoreactive trypsin (see below); and CF patients classified as pancreatic sufficient on the basis of no history of chronic steatorrhea, lack of the need for pancreatic enzyme supplements, and plasma immunoreactive trypsin levels comparable to the control group (see "Results"). All CF patients had sweat chloride levels greater than $70 \mathrm{mEq} /$ liter as determined by the Gibson-Cooke method (20) plus at least one of the major diagnostic criteria (chronic obstructive lung disease, maldigestion, sibling with $\mathrm{CF}$ ). Patients were scored clinically by a modification (10) of the Shwachman-Kulczycki method (43). All studies were approved by the local Institutional Review Board.

Preparation of erythrocyte ghosts. The procedure used was a modification of the method of Farrance and Vincenzi (13) for preparing erythrocyte ghosts depleted of calmodulin. Ten-ml blood samples were collected in citrate-phosphate, anticoagulant buffer, stored at $4^{\circ} \mathrm{C}$, and the ghosts were prepared and analyzed within $48 \mathrm{~h}$. The blood was centrifuged and the cells washed 4 times with $155 \mathrm{mM} \mathrm{NaCl}$, sequentially discarding the buffy coat; the plasma was saved for the immunoreactive trypsin determination. Approximately $4 \mathrm{ml}$ of packed, washed cells were lysed with 10 volumes of ice-cold $20 \mathrm{mM}$ imidazole buffer, $\mathrm{pH} 7.6$, containing $0.5 \mathrm{mM}$ EGTA $(22 \mathrm{mosm})$ and the membranes sedimented by centrifugation for $20 \mathrm{~min}$ at $35,000 \times g$ in a Sorvall RC-2B centrifuge. The fluffy pellet ("whitish button" was discarded) was washed 4 times with $20 \mathrm{mM}$ imidazole buffer, $\mathrm{pH} 7.6$, or until the membranes were free of hemoglobin. The final pellet was resuspended in 1 volume of the same imidazole buffer to which was added $0.2 \mathrm{mg} / \mathrm{ml}$ saponin (11) and assayed for ATPase activity within $4 \mathrm{~h}$. Membrane protein was measured by the Lowry method (33) using bovine serum albumin as the standard.

Lysis of erythrocytes in low osmolar solutions promotes dissociation of calmodulin from the Ca-ATPase which is also dependent on a low free $\mathrm{Ca}^{2+}$ concentration (13). Addition of 0.5 mM EGTA to the lysis buffer in general reduced the basal, calcium-stimulated ATPase activity but not the calmodulinstimulated, maximal activity. In our experience, the use of saponin at $0.2 \mathrm{mg} / \mathrm{ml}$ in the final suspension buffer frequently, but not always, increased both the basal and calmodulin-stimulated ATPase activity. Downes et al. (11) have suggested the inclusion of saponin to open any ghosts which may have spontaneously resealed and have found that this level of the detergent does not appear to directly alter the Ca-ATPase activity. The latter is also the experience of Vincenzi (46) and our own control experiments.

ATPase assay. The assay of membrane ATPase activities was also by the method of Farrance and Vincenzi (13). One hundred $\mu \mathrm{l}$ of membranes $(\sim 0.2 \mathrm{mg}$ protein) were assayed at $\mathrm{pH} 7.1$ in a $2 \mathrm{ml}$ reaction mixture containing $80 \mathrm{mM} \mathrm{NaCl}, 30 \mathrm{mM} \mathrm{KCl}, 18$ mM histidine, $18 \mathrm{mM}$ imidazole, $4 \mathrm{mM} \mathrm{MgCl}$, $3 \mathrm{mM}$ ATP, 0.5 mM EGTA, $0.1 \mathrm{mM}$ ouabain, and a free $\mathrm{Ca}^{2+}$ concentration of between $0.01 \mu \mathrm{M}$ and $1 \mathrm{mM}$. Calcium-EGTA buffers at free $\mathrm{Ca}^{2+}$ concentrations from pCa 8.0 to 3.0 were made accordingly to a computer program (Dr. B. Lindley, Department of Physiology) which takes into account $\mathrm{Ca}^{2+}$ binding to EGTA, ATP, and imidazole at $37^{\circ} \mathrm{C}$ and $\mathrm{pH} 7.10$. These buffers were checked and corrected by measurements with an Orion Ca-selectrode [calibrated by the methods of Bers (4)] under the same conditions as in the ATPase assay.

The membranes were preincubated in the assay medium at various $\mathrm{pCa}$ values for $20 \mathrm{~min}$ at $37^{\circ} \mathrm{C}$ in the absence of ATP. Purified bovine testicular calmodulin (see below) was added to a set of the tubes at the beginning of the preincubation to a concentration of $1.3 \mu \mathrm{g} / \mathrm{ml}$ (saturating under these conditions) in order to measure Ca-dependent, calmodulin stimulation of the ATPase. The reaction was begun with the addition of ATP to a final concentration of $3 \mathrm{mM}$ and the tubes incubated for 60 min at $37^{\circ} \mathrm{C}$ in a constant temperature water bath. The reaction was stopped with the addition of $1 \mathrm{ml}$ of $10 \%$ sodium dodecyl sulfate (determined to be phosphate-free). An aliquot from each tube was assayed for orthophosphate by the method of Chen et al. (6) in order to determine the amount of ATP hydrolysis. Identical tubes with ATP but without membranes were used to determine spontaneous ATP hydrolysis. Measurements of $(\mathrm{Na}$ $+\mathrm{K})$-ATPase activity were performed concomitantly in a reaction mix identical to the above with free pCa of 8.0 , but in the absence of ouabain.

Purification of calmodulin. Since mammalian calmodulin is essentially invariant and since human erythrocyte calmodulin 
has been shown (26) to be indistinguishable from bovine brain calmodulin, we elected to purify this ubiquitous protein from bovine testes, a tissue having a high content of calmodulin. The procedure used was adapted to bovine testes with the help of Dr. T. H. Crouch, University of Cincinnati School of Medicine, from the procedure he and coworkers have described for bovine brain (8). The final calmodulin preparation was $>95 \%$ free of contaminants as judged by sodium dodecyl sulfate-polyacrylamide gel electrophoresis (31) and ultraviolet spectral analysis with and without calcium. The purified calmodulin produced a $6-8$-fold increase in the activity of cyclic nucleotide phosphodiesterase (from bovine heart, prepared by us with the method of Ho et al. (23); this activation was inhibited by trifluoperazine with a $K_{i}$ of about $5 \mu \mathrm{M}$ (Dearborn and Poncz, unpublished).

Immunoreactive trypsin assay. Plasma samples retained from the blood samples used for erythrocyte ghost preparations were stored at $-20^{\circ} \mathrm{C}$ until assayed. All samples were centrifuged to remove debris prior to assay. Aliquots of $100 \mu \mathrm{l}$ were assayed for trypsin (trypsinogen) using a Becton-Dickenson radioimmunoassay kit according to the manufacturer's directions. Control studies using other blood samples split into serum fractions and plasma fractions anticoagulated with phosphate-buffered citrate, indicated that the anticoagulant did not significantly affect the assay.

Statistical analysis. The significance of the difference of the means was assessed by unpaired Student's $t$ test. Correlation coefficients were evaluated by linear regression, and the corresponding significance levels were determined by standard methods involving the $Z^{\prime}$ transformation of $Y$.

\section{RESULTS}

The characteristics of the study populations are given in Table 1. The mean clinical score of the CF patients with pancreatic sufficiency is better than the group with pancreatic insufficiency which is consistent with the observations reported by Gaskin et al. (19). The initial segregation of the CF patients into these two subpopulations was based on clinical criteria which were subsequently corroborated by the plasma immunoreactive trypsin levels. The control group values for plasma immunoreactive trypsin ranged from 10.4 to $48.5 \mathrm{ng} / \mathrm{ml}(23.2 \pm 11.5 \mathrm{SD})$ and showed a positive correlation with age $(r=0.661 ; p<0.001)$. Figure 1 depicts the plasma immunoreactive trypsin levels as a function of age for all three groups. The immunoreactive trypsin values for the $\mathrm{CF}$ patients classified as pancreatic sufficient (range, $9.3-88.2 \mathrm{ng} / \mathrm{ml} ; 36.0 \pm 29.7$ ) are all comparable to or above the values for controls. When age was taken into account, the values for the pancreatic insufficient patients (range, 4.9$13.3 \mathrm{ng} / \mathrm{ml} ; 6.3 \pm 1.5 \mathrm{ng} / \mathrm{ml}$ ) are all below the values of both the control and the pancreatic sufficient groups except for one patient (who did require pancreatic enzyme therapy). These results are similar to those of Durie et al. (12) who found an excellent correlation between serum immunoreactive trypsin levels and both duodenal aspirate evaluation of pancreatic function and fat absorption studies.

The ATPase activities of erythrocyte membranes were measured as a function of free $\mathrm{Ca}^{2+}$ concentration for each subject. Figure 2 illustrates a typical paired experiment comparing the ATPase activities of a control subject to those of a pancreatic insufficient $\mathrm{CF}$ patient. The pCa profile for Ca-ATPase was determined for both basal activity and calmodulin-stimulated

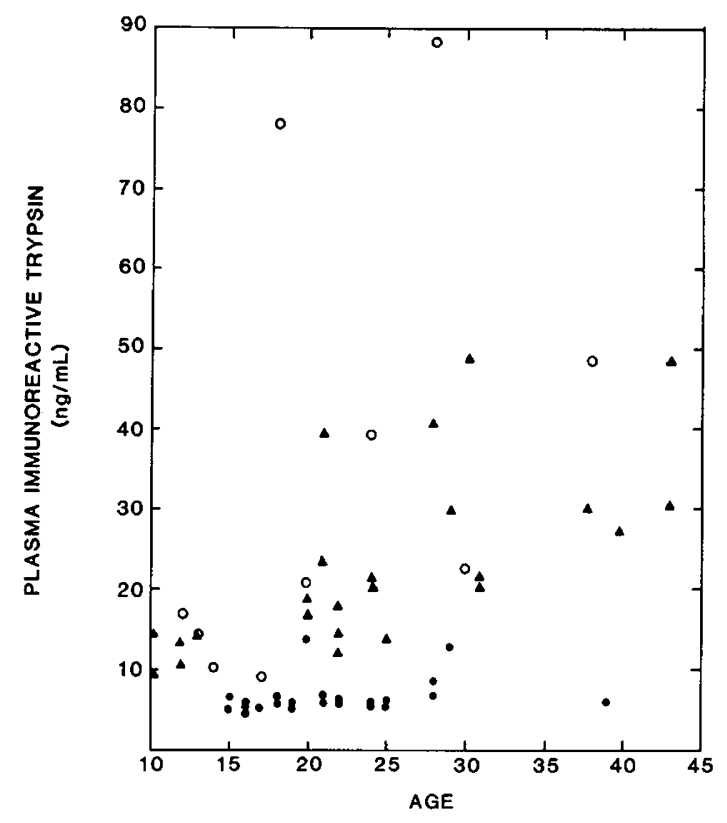

Fig. 1. Plasma immunoreactive trypsin levels as a function of subject's age. Control, $\boldsymbol{\Delta}$; cystic fibrosis with pancreatic insufficiency, $\mathbf{0}$; cystic fibrosis with pancreatic sufficiency, $\mathrm{O}$.

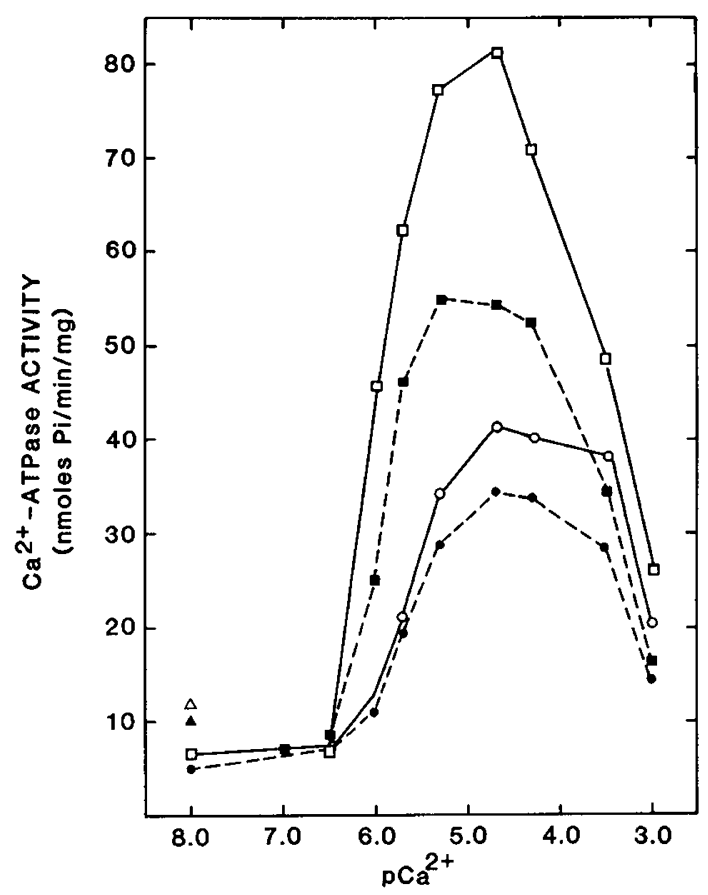

Fig. 2. Example of a paired experiment comparing the erythrocyte membrane $\mathrm{Ca}^{2+}$-ATPase activities as a function of free $\mathrm{Ca}^{2+}$ for a cystic fibrosis patient and an age- and sex-matched healthy control. Open symbols and solid lines denote control; closed symbols and broken lines

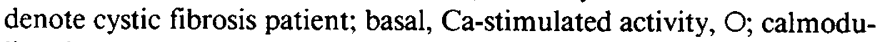
lin-stimulated activity, $\square ;(\mathrm{Na}+\mathrm{K})$-ATPase activity, i.e. no ouabain, $\Delta$.

Table 1. Characteristics of study populations

\begin{tabular}{|c|c|c|c|c|c|c|}
\hline & \multirow[b]{2}{*}{$n$} & \multirow{2}{*}{$\begin{array}{l}\text { Sex } \\
M: F\end{array}$} & \multicolumn{2}{|c|}{ Age } & \multirow{2}{*}{$\begin{array}{c}\text { Clinical score } \\
\text { mean } \pm \text { SD }\end{array}$} & \multirow[b]{2}{*}{ Range } \\
\hline & & & Mean \pm SD & Range (yr) & & \\
\hline Control & 24 & $11: 13$ & $25.1 \pm 9.5$ & $10-43$ & & \\
\hline CF-pancreatic sufficient & 10 & $8: 2$ & $21.3 \pm 8.5$ & $12-38$ & $79.9 \pm 15.0$ & $40-90$ \\
\hline CF-pancreatic insufficient & 27 & $12: 15$ & $21.1 \pm 5.1$ & $15-39$ & $63.6 \pm 15.4$ & $32-88$ \\
\hline
\end{tabular}


activity. Exogenous calmodulin purified from bovine testes was added to the calmodulin-depleted membranes to a final concentration of $1.3 \mu \mathrm{l} / \mathrm{ml}$. This is well beyond saturating conditions in that half-maximal activation was observed to be approximately $91 \mathrm{ng} / \mathrm{ml}(5.5 \mathrm{nM})$ calmodulin and the addition of more calmodulin did not increase the maximal Ca-ATPase activity. The Mg-ATPase activity is considered to be the ATPase activity at pCa of 8.0 (with ouabain present) which, in general, was a very small fraction of the maximal ATPase activity. This activity can be eliminated by prior incubation of the membranes at $37^{\circ} \mathrm{C}(9)$, but in our experiments the Mg-ATPase activity was usually less than $5 \mathrm{nmol} / \mathrm{min} / \mathrm{mg}$ protein and was therefore considered background ATPase activity and subtracted to determine the calcium-dependent ATPase activities.

The basal Ca-ATPase activity was taken as the maximal enzyme activity observed with the pCa profile in the absence of calmodulin minus the Mg-ATPase activity. The activity maximum generally occurred between pCa values of 5.0 to 4.5 , with decreased activity observed at lower values of $\mathrm{pCa}$. This falling off at high free $\mathrm{Ca}^{2+}$ concentrations, more prominent in the presence of calmodulin, has been observed by other investigators and is not totally explained but may be in part due to binding competition between Ca-ATP and the substrate Mg-ATP (9). The calmodulin-stimulated Ca-ATPase activity was taken as the maximal activity in the presence of the saturating concentration of calmodulin minus the Mg-ATPase activity. The data obtained from these experimental curves are not suitable for the estimation of Michaelis constants because of the effects of the EGTA used to control free $\mathrm{Ca}^{2+}$ concentrations (9). The average $\mathrm{pCa}$ values at half-maximal activity were approximately 5.8 and 5.2 , in the presence and absence of calmodulin, respectively, and no sig- nificant differences were noted between $\mathrm{CF}$ and control data. The $(\mathrm{Na}+\mathrm{K})$-ATPase activity was taken as the difference in ATPase activities at pCa 8.0 in the presence and absence of ouabain.

The results of the ATPase assays are presented for the three study populations in Figure 3 and Table 2 . The control $\mathrm{Ca}-$ ATPase activities are comparable to those of other investigators using the imidazole lysis buffer for erythrocyte membrane preparation (13). These values are almost 1000 times higher than the activities reported by Katz and Emery (30) but similar to those reported by Foder et al. (18). The intersubject variability is also comparable to other reports (36). The Ca-ATPase activities for an individual control subject studied 8 times over a 4-month period using the same conditions of membrane preparation and ATPase assays were: basal Ca-ATPase activity, $29.5 \pm 5.9 \mathrm{nmol} /$ $\mathrm{min} / \mathrm{mg}$ protein, range $=25-40$; and calmodulin-stimulated $\mathrm{Ca}$ ATPase activity, $74.8 \pm 11.3 \mathrm{nmol} / \mathrm{min} / \mathrm{mg}$ protein, range $=$ $60-89$. The exact source(s) of the variability is unclear, but would appear to include intrasubject changes with time due to unknown factors.

In comparing the $\mathrm{CF}$ pancreatic insufficient population with controls, there is a statistically significant decrease in the mean basal Ca-ATPase activity $(20 \%, p<0.02)$ as there is in the mean calmodulin-stimulated Ca-ATPase activity $(23 \%, p<0.001)$. However, the mean Ca-ATPase activities for the CF-pancreatic sufficient population are intermediate between the control and pancreatic insufficient patients and are not statistically distinguishable from controls. The mean basal activities for the two CF groups do not differ significantly $(p>0.1)$ while the differences in calmodulin-stimulated activities approach statistical significance $(p<0.1)$. The $(\mathrm{Na}+\mathrm{K})$-ATPase activities of the

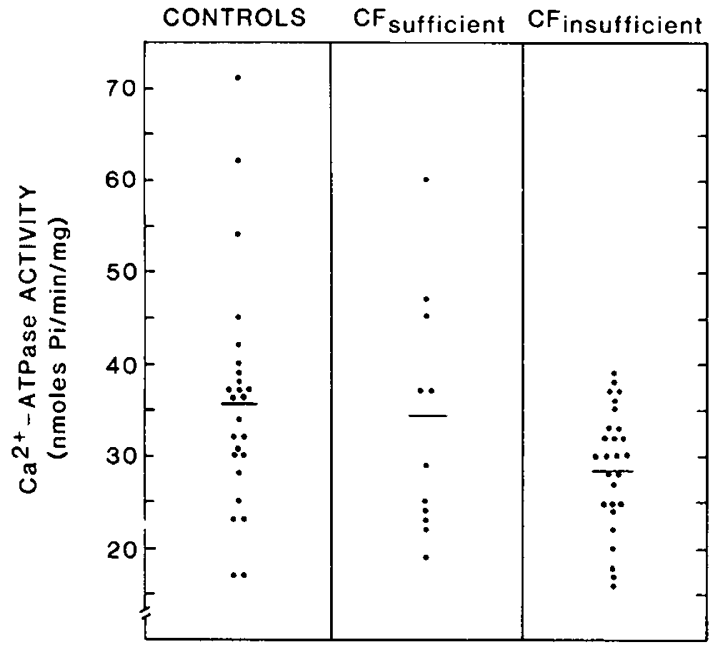

A. BASAL $\mathrm{Ca}^{2+}-$ ATPase ACTIVITY

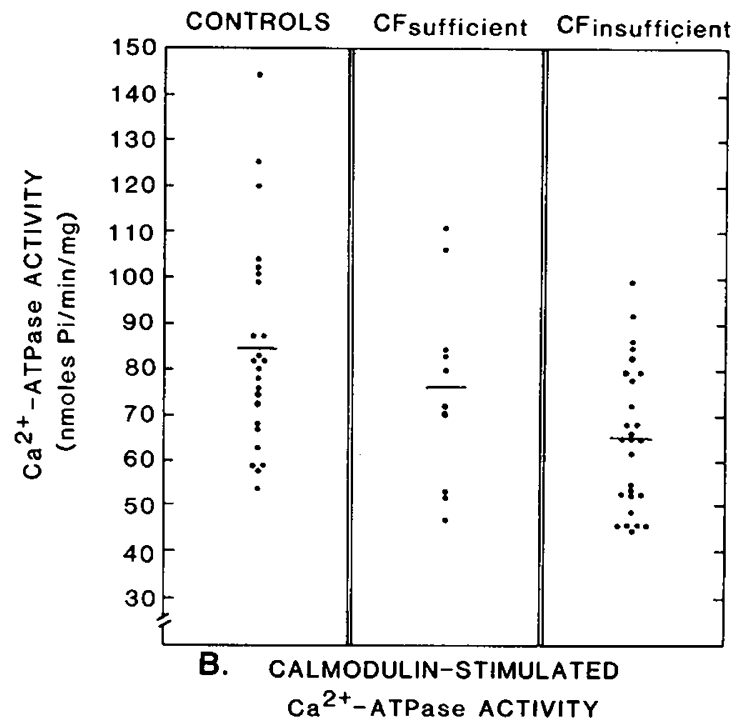

Fig. 3. Maximal Ca-ATPase activities of the three study populations. $A$, basal, Ca-stimulated activities; $B$, Ca-calmodulin-stimulated activities. See the legend to Table 2 for the statistical comparisons.

Table 2. Comparison of ATPase activities*

\begin{tabular}{|c|c|c|c|}
\hline & \multicolumn{2}{|c|}{ Ca-ATPase } & \multirow{2}{*}{$\begin{array}{c}(\mathrm{Na}+\mathrm{K})- \\
\text { ATPase } \\
\text { mean } \pm \mathrm{SEM}, p \dagger\end{array}$} \\
\hline & $\begin{array}{c}\text { Basal } \\
\text { mean } \pm \mathrm{SEM}, p \dagger\end{array}$ & $\begin{array}{l}\text { Calmodulin-stimulated } \\
\text { mean } \pm \mathrm{SEM}, p \dagger\end{array}$ & \\
\hline Controls (24) & $35.8 \pm 2.6$ & $84.3 \pm 4.7$ & $13.4 \pm 1.1$ \\
\hline CF-pancreatic sufficient (10) & $35.3 \pm 4.2 \mathrm{NS}$ & $75.9 \pm 6.9 \mathrm{NS}$ & $13.3 \pm 1.4 \mathrm{NS}$ \\
\hline CF-pancreatic insufficient (27) & $28.9 \pm 1.3<0.02$ & $65.2 \pm 3.0<0.001 \ddagger$ & $10.6 \pm 0.8<0.025$ \\
\hline
\end{tabular}

* Activities in $\mathrm{nmol} / \mathrm{min} / \mathrm{mg}$ protein; Ca-ATPase activities are maximal values observed as function of pCa (see "Materials and Methods"). Number of subjects is in parentheses; averages of intrasubject values were used where an individual was studied more than once. NS, not significant. $\dagger$ Unpaired, single-tailed Student's $t$ test; compared to controls.

$\ddagger p<0.1$ compared to CF-pancreatic sufficient. 


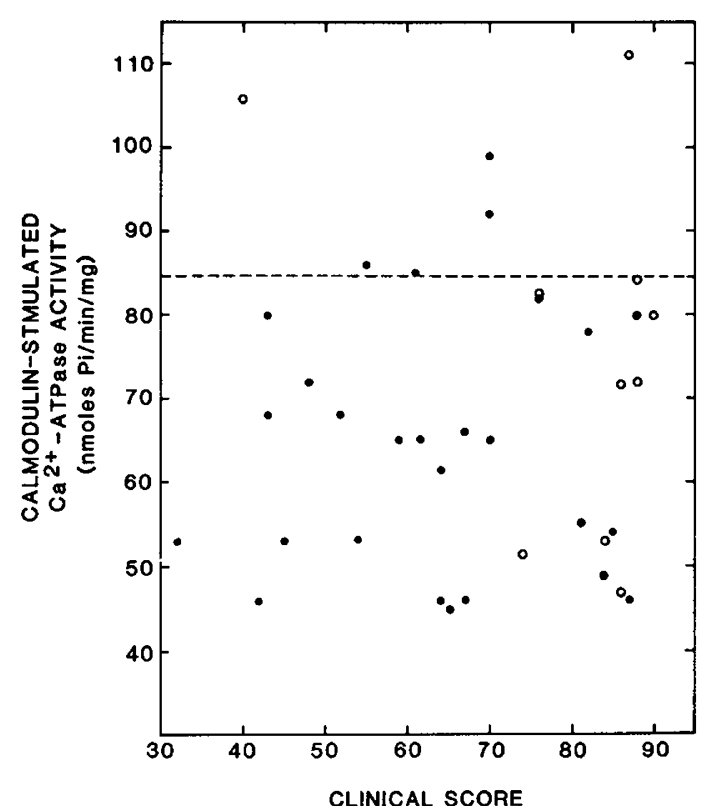

Fig. 4. Maximal calmodulin-stimulated $\mathrm{Ca}^{2+}-\mathrm{ATP}$ ase activities as a function of clinical scores of the cystic fibrosis patients. Pancreatic sufficient patients; $\mathrm{O}$; pancreatic insufficient patients, $\bullet$; dotted line is the mean activity for the control group.

CF-pancreatic insufficient group also showed a decrease $(21 \%)$ compared to the control group which was marginally significant $(p<0.025)$; the CF-pancreatic sufficient group did not differ from the control group. No significant correlation was found between any of the ATPase activities and either sex or age within any of the three groups of subjects or for the entire study population.

A difference in general clinical status is one possible source of the different Ca-ATPase activities of the two CF populations since the pancreatic sufficient group had a significantly higher mean clinical score $(p<0.005)$. However, this is not apparent from Figure 4 which compares calmodulin-stimulated Ca-ATPase activities with the clinical scores. Statistical comparison of these two parameters failed to reveal any correlation either within each of the CF groups or for the entire CF study population. Comparison of the Ca-ATPase activities of those patients studied while they were hospitalized for intensive therapy for pulmonary infection with patients studied as outpatients also did not demonstrate any statistical correlations.

\section{DISCUSSION}

We have demonstrated a significant decrease in the Ca-ATPase activity, both in the presence and absence of the activator protein calmodulin, in a population of $\mathrm{CF}$ patients with pancreatic exocrine insufficiency. In contrast, a subpopulation of $\mathrm{CF}$ patients who do not have a history of steatorrhea, do not require pancreatic enzyme replacement, and have normal or high levels of plasma immunoreactive trypsin has average Ca-ATPase activities which are indistinguishable from controls. Foder et al. (18), using a method of erythrocyte membrane preparation which should ensure the retention of calmodulin binding to the $\mathrm{Ca}$ ATPase, have found a $15 \%$ decrease in maximal Ca-ATPase of CF erythrocyte membranes compared to controls. Our observed decrease of about $25 \%$ in the calmodulin-stimulated Ca-ATPase for the pancreatic insufficient patient group may be due to differences in methodology.

While Balfe et al. (2) found the activities of ouabain-sensitive ATPase of CF erythrocyte membranes to be decreased by about $30 \%$, subsequent investigators $(7,16,22,27,32,35)$ have observed that any decreased $(\mathrm{Na}+\mathrm{K})$-ATPase activities are not significantly different from control activities. Our finding of a marginally significant decrease in the pancreatic insufficient subpopulation probably reflects technical and perhaps patient population differences from these studies.

Previous reports on Ca-ATPase activities in CF erythrocyte membranes other than that of Foder et al. (18) did not report attempts to compare the observed activities with any criteria of patient clinical status $(1,7,16,24,27-30,35)$. In contrast to our findings of differences based on exocrine pancreatic status, we failed to observe any correlation of $\mathrm{Ca}$-ATPase activities with either general clinical status as documented by a standard fourpart clinical scoring system $(10,43)$ or acute clinical status as judged by the need for hospitalization for intensive pulmonary therapy versus comparatively healthy outpatients. This agrees in general with the findings of Foder et al. (18) as does our failure to observe any correlation between Ca-ATPase activities and sex or age. However, the high degree of inter- and intrasubject variability together with the rather subjective nature of the clinical criteria may obscure any more subtle, disease-related correlations. Our results together with those of Foder et al. (18), who in addition found no Ca-ATPase activity difference between controls and patients with other chronic pulmonary diseases, suggest that advanced lung involvement is not a source of the decreased Ca-ATPase activity.

The large amount of overlap in the activities observed between controls and even the pancreatic insufficient CF patients argues against decreased Ca-ATPase activity being the primary defect in this disorder, although until there is a better understanding of the source of subject variability this cannot be entirely ruled out. Two general explanations for the different mean activities of the two CF subpopulations can be considered. Heterogeneity within $\mathrm{CF}$ is well recognized (44) and genetic polymorphism in the $\mathrm{Ca}$ ATPase may be intrinsic to the differences in pancreatic status. Perhaps more likely, the maldigestion and malabsorption accompanying pancreatic deficiency may affect the Ca-ATPase activity through nutritional alterations. Deficient lipid nutrition in these patients has been noted to be reflected in altered fatty acid (25) and phospholipid (39) composition of erythrocyte membranes, decreased circulating and tissue levels of fat-soluble vitamins (especially vitamins $\mathrm{E}$ and $\mathrm{A})(14,15,45)$ and decreased in vivo erythrocyte survival times (14). Studies of both intact erythrocyte membranes (40) and purified, reconstituted Ca-ATPase (18) indicate that the enzyme activity is very sensitive to lipid composition. Similarly, the activity of $(\mathrm{Na}+\mathrm{K})$ ATPase is also known to be dependent upon the lipid environment $(37,38)$. Investigations of these factors in both CF subjects and other patients with pancreatic insufficiency and/or altered lipid nutrition are logical future areas for study.

\section{REFERENCES}

1. Ansah T, Katz S 1980 Evidence for a $\mathrm{Ca}^{2+}$-transport deficiency in patients with cystic fibrosis. Cell Calcium 1:195

2. Balfe JW, Cole C, Welt LG 1968 Red cell transport defect in patients with cystic fibrosis and their parents. Science 162:689

3. Bauschbach MW, Kayarn AG, Love PK 1978 Cystic fibrosis serum promotes ${ }^{45} \mathrm{Ca}$ uptake by normal human leukocytes. Biochem Biophys Res Commun 84:922

4. Bers DM 1982 A simple method for the accurate determination of free $\mathrm{Ca}$ in Ca-EGTA solutions. Am J Physiol 242:C404

5. Carafoli E, Zurini M, Niggli V. Krebs J 1982 The calcium-transporting ATPase of erythrocytes. Ann NY Acad Sci 402:304

6. Chen PS, Toribara TY, Warner H 1956 Microdetermination of phosphorus. Anal Chem 28:1756

7. Cole CH, Dirks JH 1972 Changes in erythrocyte membrane ATPase in patients with cystic fibrosis of the pancreas. Pediatr Res 6:616

8. Crouch TH, Holroyde MJ, Collins JH, Solaro RJ, Potter JD 1981 Interaction of calmodulin with skeletal muscle myosin light chain kinase. Biochemistry 20:6318

9. Cox JA. Conte M, Stein EA 1982 Activation of human erythrocyte $\mathrm{Ca}^{2+}$. dependent $\mathrm{Mg}^{2+}$-activated ATPase by calmodulin and calcium: quantitative analysis. Proc Natl Acad Sci USA 79:4265

10. Doershuk CF, Matthews LW, Tucker AS, Nudelman H, Eddy G, Wise M, Spector S 1964 A five year clinical evaluation of a therapeutic program for patients with cystic fibrosis. J Pediatr 65:677 
11. Downes CP Simmonds SH, Michell RH 1981 Apparent variations in the activation characteristics of human erythrocyte membrane $\mathrm{Ca}^{2+}$-pump ATPase may be caused by variable membrane permeability. Cell Calcium $2: 473$

12. Durie PR, Largman C, Brodrick JW, Johnson JH, Gaskin KJ, Forstner GG, Geokas MC 1981 Plasma immunoreactive pancreatic cationic trypsinogen in cystic fibrosis: a sensitive indicator of exocrine pancreatic dysfunction Pediatr Res 15:1351

13. Farrance $\mathrm{ML}$, Vincenzi $\mathrm{FF} 1977$ Enhancement of $\left(\mathrm{Ca}^{2+}+\mathrm{Mg}^{2+}\right)$-ATPase activity of human erythrocyte membranes by hemolysis in isoosmotic imidazole buffer. Biochim Biophys Acta 471:59

14. Farrell PM. Bieri JG, Fratantoni JF, Wood RE, de Sant'Agnese PA 1977 The occurrence and effects of human vitamin $E$ deficiency. J Clin Invest 60:233

15. Fartell PM, Mischler EH, Gutcher GR 1982 Evaluation of vitamin E deficiency in children with lung disease. Ann NY Acad Sci 393:96

16. Feig SA, Segel GB, Kern KA, Osher A, Schwartz RH 1974 Erythrocyte transport function in cystic fibrosis. Pediatr Res 8:594

17. Feigal RJ, Shapiro BL 1979 Mitochondrial calcium uptake and oxygen consuption in cystic fibrosis. Nature 278:276

18. Foder B, Scharff O, Tonnesen P 1980 Activator-associated $\mathrm{Ca}^{2+}$-ATPase in erythrocyte membranes from cystic fibrosis patients. Clin Chim Acta 104:187

19. Gaskin K Gurwitz D, Durie P, Corey M, Levison H, Forstner G 1982 Improved respiratory prognosis in patients with cystic fibrosis with normal fat absorption. J Pediatr 100:857

20. Gibson LE, Cooke RE 1959 A test for concentration of electrolytes in sweat in cystic fibrosis of the pancreas utilizing pilocarpine iontophoresis. Pediatrics $23 \cdot 545$

21. Graf E, Verma AK, Gorski JP, Lopaschuk G, Niggli V, Zurini M, Carafoli E, Penniston JT 1982 Molecular properties of calcium-pumping ATPase from human erythrocytes. Biochemistry 21:4511

22. Hadden JW, Hansen LG, Shapiro BL, Warwick WJ 1973 Erythrocyte enigmas in cystic fibrosis. Proc Soc Exp Biol Med 142:577

23. Ho HC. Teo TS. Desai R, Wang JH 1976 Catalytic and regulatory properties of two forms of bovine heart cyclic nucleotide phosphodiesterase. Biochim Biophys Acta 429:461

24. Horton CR, Cole WO, Bader H 1970 Depressed $\left(\mathrm{Ca}^{2+}\right)$-transport ATPase in cystic fibrosis erythrocytes. Biochem Biophys Res Commun 40:505

25. Hubbard, US, and Dunn GD Fatty acid composition of erythrocyte phospholipids from patients with cystic fibrosis. Clin Chim Acta 102:115

26. Jarrett HW, Kyle J 1979 Human erythrocyte calmodulin. Further chemical characterization and the site of its interaction with the membrane. $J$ Biol Chem 254:8237

27. Katz S 1978 Calcium and sodium transport processes in patients with cystic fibrosis. I. A specific decrease in $\mathrm{Mg}^{2+}$-dependent, $\mathrm{Ca}^{2+}$-adenosine triphosphatase activity in erythrocyte membranes from cystic fibrosis patients. Pediatr Res 12:1033

28. Katz S $1980 \mathrm{Ca}^{2+}$-transport and $\left(\mathrm{Mg}^{2+}+\mathrm{Ca}^{2+}\right)$-ATPase activity in cystic fibrosis patients. In. Sturgess $\mathbf{J}$ (ed) Proceedings of the Eighth International Congress on Cystic Fibrosis. Imperial Press Ltd, Mississauga, Ontario, Canada, p 3
29. Katz S, Ansah T $1980\left(\mathrm{Mg}^{2+}+\mathrm{Ca}^{2+}\right)$-ATPase activity in plasma membrane enriched preparations of human skin fibroblasts: decreased activity in fibroblasts derived from cystic fibrosis patients. Clin Chim Acta 100:245

30. Katz S, Emery DL 1981 The role of calmodulin in the regulation of $\left(\mathrm{Mg}^{2+}+\right.$ $\left.\mathrm{Ca}^{2+}\right)$-ATPase activity in erythrocyte membranes of cystic fibrosis patients and controls. Cell Calcium 2:545

31. Laemmli UK 1970 Cleavage of structural proteins during the assembly of the head of bacteriophage. Nature 227:680

32. Lapey A, Gardner JD 1970 Abnormal erythrocyte sodium transport in cystic fibrosis. Pediatr Res 4:478

33. Lowry OH, Rosebrough NJ, Farr AL, Randall RJ 1951 Protein measurement with the Folin phenol reagent. J Biol Chem 193:265

34. Mangos JA, Donnelly WH 1981 Isolated parotid acinar cells from patients with cystic fibrosis. Morphology and composition. J Dent Res 60:19

35. McEvoy FA, Davies RJ, Goodchild MC, Anderson CM 1974 Erythrocyte membrane properties in cystic fibrosis. Clin Chim Acta 54:195

36. Reinila M, MacDonald E, Salem N, Linnoila M, Trams EG 1982 Standardized method for the determination of human erythrocyte membrane adenosine triphosphatase. Anal Biochem 124:19

37. Roelofsen B, VanDeenen LLM 1973 Lipid requirement of membrane-bound ATPase. Studies on human erythrocyte ghosts. Eur J Biochem 40:245

38. Roelofsen B, Van Linde-Sibenius Trip M 1981 The fraction of phosphatidylinositol that activates the $\left(\mathrm{Na}^{+}+\mathrm{K}^{+}\right)$-ATPase in rabbit kidney microsomes is closely associated with the enzyme protein. Biochim Biophys Acta 647:302

39. Rogiers V, Crokaert R, Vis H 1980 Altered phospholipid composition and changed fatty acid pattern of the various phospholipid fractions of red cell membranes of cystic fibrosis children with pancreatic insufficiency. Clin Chim Acta 105:105

40. Ronner P, Gazzotti P, Carafoli E 1977 A lipid requirement for the $\left(\mathrm{Ca}^{2+}+\right.$ $\mathrm{Mg}^{2+}$ )-activated ATPase of erythrocyte membranes. Arch Biochem Biophys 179:S78

41. Roufogalis BD, Akyempon CK, Al-Jobore A, Minocherhomjee AM 1982 Regulation of the $\mathrm{Ca}^{2+}$ pump of the erythrocyte membrane. Ann NY Acad Sci 402:349

42. Shapiro BL, Feigal RJ, Lam LFH 1980 Intracellular calcium and cystic fibrosis In: Sturgess J (ed) Proceedings of the Eighth International Congress on Cystic fibrosis. Imperial Press Ltd, Mississauga, Ontario, Canada, p 15

43. Shwachman $\mathrm{H}$, Kulczycki LL 1958 Long term study of 105 patients with cystic fibrosis: studies made over 5 to 14 year period. Am J Dis Child 96:6

44. Sing CF, Risser DR, Howatt WF, Erickson RP 1982 Phenotypic heterogeneity in cystic fibrosis. Am J Med Genet 13:179

45. Underwood BA, Denning CR, Navab M 1972 Polyunsaturated fatty acids and tocopherol levels in patients with cystic fibrosis. Ann NY Acad Sci 203.237

46. Vincenzi FF 1982 Pharmacological modification of the $\mathrm{Ca}^{2+}$-pump ATPase activity of human erythrocytes. Ann NY Acad Sci 402:368

47. Vincenzi FF, Hinds TR 1980 Calmodulin and plasma membrane calcium transport. In: Cheung WY (ed) Calcium and Cell Function. Academic Press, New York, p 127 